 \\ XXVI Congresso de Iniciação Cientifica Unicamp
}

\section{Associativismo e imigração portuguesa no interior paulista, de 1880 a 1950}

\author{
Giulia Giacomini Kiefer*, Ana Silvia Volpi Scott.
}

\section{Resumo}

A pesquisa propôs o estudo de práticas associativas entre os imigrantes portugueses no interior paulista, de 1880 a 1950, com foco nas Beneficências Portuguesas que se encontram no dado recorte espacial, dando-se destaque para a instituição fundada na cidade de Campinas.

\section{Palavras-chave:}

Imigração portuguesa; Campinas; associativismo.

\section{Introdução}

Esta pesquisa integra o projeto financiado pela FAPESP, "Percursos histórico-sociais na incorporação de imigrantes no oeste paulista (1880-1950)". O subprojeto em andamento tem como foco a experiência associativa portuguesa no recorte temporal mencionado. $O$ projeto mais amplo reúne pesquisadores e bolsistas de universidades paulistas. A partir, aproximadamente, da segunda metade do século XIX, com a gradual abolição da escravatura e a necessidade de mão de obra barata por conta da expansão da cafeicultura, registrou-se a entrada de imigrantes no território paulista. Através do associativismo, os imigrantes estrangeiros, especialmente portugueses buscavam formas de proteção e amparo. De acordo com Moya (2011) e Rocha-Trindade (2010), o principal impulsionador das práticas associativas é o próprio processo migratório.

Vale destacar ainda, que o estudo das associações de imigrantes portugueses permite analisar os diferentes mecanismos de chegada e inserção na sociedade brasileira, pois identificam os naturais de Portugal, que se tornavam "invisíveis", pois compartilhavam nomes e características semelhantes à população brasileira em geral (Scott, 2000).

\section{Resultados e Discussão}

A Beneficência Portuguesa, fundada em 1873, mantém acervo documental depositado na instituição, que funciona até hoje. Além desse material (atas, livros de entrada de doentes, etc), ampliou-se a busca para outros acervos da UNICAMP), que incluíram jornais da época e Ribeirão Preto.

Entre as fontes principais destaca-se a obra intitulada Registro Histórico da Real Sociedade Portuguesa de Beneficência 1873 - 1960, que reúne farto material, e que estava disponível na própria instituição. A partir desta, foi possível recompor a trajetória da fundação, os estatutos, os discursos que reforçavam a identidade portuguesa, assim como, a outra faceta desse grupo de imigrantes que deu visibilidade a dissidências e conflitos no interior do grupo de associados, apesar de todo o discurso de identidade e de forte ligação com a terra natal. Com base em relatórios e atas, assim como através de matérias publicadas em jornais da época, vieram à tona processos variados, tanto aqueles que visavam reforçar os laços entre a comunidade portuguesa, radicada em Campinas, como as disputa que dividiam o grupo.
Destacam-se as tentativas de criação de novas instituições de benemerência, como a Sociedade Portuguesa de Socorros Mútuos e a Sociedade Portuguesa de União e Caridade, em 1904 e 1888, respectivamente. A primeira possuiu uma articulação maior e perdurou até a metade da década de 1960, quando sofreu fusão com a Beneficência Portuguesa; a segunda surgiu após a revolta dos portugueses com a decisão da Santa Casa de Misericórdia da cidade proibir o atendimento a tal grupo étnico em pleno surto de febre amarela. No entanto, por motivos ainda não determinados, esta instituição não saiu do papel.

Foi possível perceber também a notável ativa dos sócios em questões da cidade, como o envolvimento dos médicos no movimento para a criação de uma maternidade na cidade em 1910.

\section{Conclusão}

O estudo de associações de imigrantes aparece como relevante para a compreensão da dinâmica de inserção na sociedade de acolhimento. No caso da Beneficência Portuguesa de Campinas, o caráter assistencial demonstra o interesse no fortalecimento de laços entre os portugueses que se encontravam radicados na cidade. Por outro lado, abre possibilidades para a compreender das dissidências internas, que colocavam em perspectiva a realidade, que estava, muitas vezes, afastada dos discursos de coesão e unidade dos imigrantes.

\section{Agradecimentos}

Agradeço ao programa PIBIC-UNICAMP pelo
financiamento a esta pesquisa e ao projeto FAPESP "
Percursos histórico-sociais na incorporação de
imigrantes no oeste paulista (1880-1950)" pela
integração a este subprojeto. Agradeço também a Real
Sociedade Portuguesa de Beneficência de Campinas
pela disponibilização de obras essenciais para a
realização desta pesquisa.

MOYA, José C.; MUÑOZ, Patricia. Las asociaciones de inmigrantes: en búsqueda de pautas históricas globales. Historia Social, p. 9-41, 2011. ROCHA-TRINDADE, Maria Beatriz - Associativismo em contexto migratório $=$ Associativism in the context of migration [Em linha]. "Revista Migrações". Associativismo imigrante. Nº6 (Abr. 2010). p. 39-58 SCOTT, Ana Silvia Volpi. Verso e reverso da imigração portuguesa: o caso de São Paulo entre as décadas de 1820 a 1930. Revista Oceanos Portugueses no Brasil Independente, Lisboa, n. 44, p. 126-142, 2000. 